\title{
P01.09. Effect of Maeg-Moon-Dong-Tang on production and secretion of respiratory mucus
}

\author{
C Lee 1* $^{*}$ H Sung ${ }^{2}, \mathrm{~J} \mathrm{Kim}^{3}$ \\ From International Research Congress on Integrative Medicine and Health 2012 \\ Portland, Oregon, USA. 15-18 May 2012
}

\section{Purpose}

Effects of maeg-moon-dong-tang (MMT) on ATP- or TNF-alpha- or PMA- or EGF-induced MUC5AC mucin production and gene expression from human airway epithelial cells and the increase in airway epithelial mucosubstances of rats were investigated.

\section{Methods}

Confluent NCI-H292 cells were pretreated for $30 \mathrm{~min}$ in the presence of MMT and treated with ATP $(200 \mu \mathrm{M})$ or PMA $(10 \mathrm{ng} / \mathrm{ml})$ or EGF $(25 \mathrm{ng} / \mathrm{ml})$ or TNF-alpha $(0.2 \mathrm{nM})$ for 24 hours, to assess the effect of MMT both on ATP- or PMA- or EGF- or TNF-alpha-induced MUC5AC mucin production using enzyme-linked immunosorbent assay (ELISA) and on gene expression by the same inducers using reverse transcription-polymerase chain reaction (RT-PCR). At the same time, hypersecretion of airway mucus was induced by exposure of rats to $\mathrm{SO}_{2}$ during 3 weeks. Effect of orallyadministered MMT during 2 weeks on increase in airway epithelial mucosubstances from tracheal goblet cells of rats was assesed using histopathological analysis after staining the epithelial tissue with PAS-alcian blue. Possible cytotoxicity of MMT was assessed by investigating the potential damage of kidney and liver function by measuring serum GOT/GPT activities and serum BUN concentration of rats and body weight gain during the experiment.

\section{Results}

(1) MMT did not only inhibit but also increased MUC5AC mucin production and expression levels of the MUC5AC gene from NCI-H292 cells. (2) MMT did not decrease the amount of intraepithelial

${ }^{1}$ Chungnam National University School of Medicine, Daejeon, Republic of Korea

Full list of author information is available at the end of the article mucosubstances in the trachea of rats. (3) MMT did not show renal or hepatic toxicity and did not affect body weight gain of rats during the experiment.

\section{Conclusion}

MMT might normalize the production and gene expression of airway mucin observed in various respiratory diseases accompanied by yin-deficiency, without in vivo toxicity to liver and kidney functions after oral administration.

\section{Author details}

${ }^{1}$ Chungnam National University School of Medicine, Daejeon, Republic of Korea. 'Dongguk Univ-Seoul, Graduate School of Oriental Medicine, Seoul, Republic of Korea. ${ }^{3}$ Dongguk Univ-Seoul, Graduate School of Oriental Medicine, Seoul, Republic of Korea.

Published: 12 June 2012

doi:10.1186/1472-6882-12-S1-P9

Cite this article as: Lee et al.: P01.09. Effect of Maeg-Moon-Dong-Tang on production and secretion of respiratory mucus. BMC Complementary and Alternative Medicine 2012 12(Suppl 1):P9.

Submit your next manuscript to BioMed Central and take full advantage of:

- Convenient online submission

- Thorough peer review

- No space constraints or color figure charges

- Immediate publication on acceptance

- Inclusion in PubMed, CAS, Scopus and Google Scholar

- Research which is freely available for redistribution
C Biomed Central

C 2012 Lee et al; licensee BioMed Central Ltd. This is an Open Access article distributed under the terms of the Creative Commons Attribution License (http://creativecommons.org/licenses/by/2.0), which permits unrestricted use, distribution, and reproduction in any medium, provided the original work is properly cited. 